\title{
Transformations of Structural Divisions of Lithuanian Higher Education Institutions: Case of the Faculty of Pedagogy at Klaipèda University
}

\author{
Aušrinè Zulumskytè
}

\begin{abstract}
Analysis of the development of the Faculty of Pedagogy of Klaipeda University and changes from 1990 to 2004 presents the nature, process, and expression of structural and content transformations in Lithuanian higher-education in the context of academic activities of teachers, researchers, and students. The case of the Faculty of Pedagogy of Klaipeda University was chosen because of the exceptional historical, geopolitical, and academic prerequisites in the initial phase of restoration of Lithuania's independence. The article focuses on the systemic and structural transformation of the Faculty of Pedagogy, touches upon problems of changes in the content of studies, and highlights the positions of professors and students in terms of achievements, negative factors, and future perspectives of the Faculty. Aspects of research, documents, academic literature, and reconstructive presentations of empiric research are employed.
\end{abstract}

Keywords: higher education, Faculty of Pedagogy of Klaipeda University, transformations, teachers, students

\section{Introduction}

Every historical period leaves a mark on the political life of a country as well as on its culture, science, and education. Transformations and challenges faced by society in specific stages of ideological and social turning points are best reflected in statistical indicators and also in the experiences of people and institutions that decide on the significance, relevance, and exceptionality of any given event. Even in a relatively small country like Lithuania with a rather unified system of higher education, during the Soviet era (similar to other Soviet republics), a number of differentiations were observed - specifically, the peculiarities, which had formed in the first half of the $20^{\text {th }}$ century when Lithuania was an independent state. The heritage of 1920s and 1930s predetermined specific transformations in the educational system (partially in higher education and research) in each Lithuanian city and region after the restoration of independence in 1990. The changes that occurred in the Lithuanian higher education system have been analysed from various perspectives by such Lithuanian scholars as Palmira Jucevičienè ${ }^{1}$, Lina

1 P. Jucevičiene, 'Universitetinès studijos profesinio rengimo kontekste' [University studies in the context of vocational training], Socialiniai mokslai [Social sciences], vol. 24, no. 3, 2000, p. 45. 
Kraujutaitytè $\dot{e}^{2}$ Rimantas Želvys and Rima Žilinskaitė ${ }^{3}$, Vaiva Zuzevičiūtè and Margarita Teresevičiene. ${ }^{4}$ However, specific aspects of development of a higher education institution or its structural divisions have seldom been analysed in academic literature.

The case of the development and transformations in the Faculty of Pedagogy of Klaipeda University (KU) from 1990 to 2004 is interesting and essential to study from the perspective of academic research, regardless of the various names this institution has had and its distinctive history from establishment in the early $20^{\text {th }}$ century ${ }^{5}$ to the end of the Soviet era $^{6}$ and after restoration of independence. ${ }^{7}$ Throughout the $20^{\text {th }}$ century, this institution trained specialists in education at various levels; ${ }^{8}$ therefore it has always been an important part of economic, social, and cultural development processes in western Lithuanian.

My study asks: 1) What challenges were faced by a division (currently the Faculty of Pedagogy of Klaipeda University) specialising in training teachers and committed to the development of education sciences in Lithuania from 1990 to 2004? 2) What were the specific activities in the general context of Lithuanian higher education transformations? 3) How were changes perceived by staff and students?

I analysed academic literature and documents using contrastive analysis and reconstructive analysis of empirical research results.

My primary sources were historical and legal documents that helped reconstruct past events and facts. Research on this topic and memoirs were also analysed, which made it possible to compare different points of view of the authors. In the final stage of the study, I surveyed students and professors, who revealed how events were evaluated by their participants. Research results are integrated, generalized, and grouped by key issues.

2 L. Kraujutaityté, Aukštojo mokslo demokratiškumo pagrindai [The foundations of democracy in higher education], Vilnius, Publishing House of Lithuanian Law University, 2002.

3 R. Želvys, R. Žilinskaite, 'Aukštojo mokslo ir profesinio rengimo kaita' [Higher education reform in Lithuania: achievements and problems], Acta paedagogica Vilnensia, no. 12, 2004, pp. 8-18.

4 V. Zuzevičiūtè, M. Teresevičienè, Universitetinés studijos mokymosi visa gyvenima perspektyvoje [University studies in the context of lifelong learning], Kaunas, VDU Publishing House, 2007.

5 O. Tijūnèlienè, Mokytoju rengimas Respublikos pedagoginiame institute 1935-1939 m. [Teacher training in the Republican Pedagogical Institute in 1935-1939], Klaipeda, KU Publishing House, 1996.

6 G. Lukauskienè, A. Zulumskytè, 'Pedagogu rengimo raida Klaipedoje 1902-1975 metais: nuo seminarijos iki pedagogikos fakulteto' [The development of teacher training in Klaipeda University in 1902-1975: from Seminary to the Faculty of Pedagogy], Tiltai [Bridges], no. 11, 2002.

7 A. Juška, 'Klaipedos mokytoju seminarijai - 90 metų [The $90^{\text {th }}$ anniversary of Klaipeda teacher training seminary], Klaipeda, 25 September 1992.

8 Klaipedos universiteto Pedagogikos fakultetas 1935-2005 [Faculty of Pedagogy of Klaipeda University in 1935-2005], Klaipeda, KU Publishing House, 2005, pp. 4-5. 


\section{Prerequisites for establishment of the Faculty of Pedagogy at Klaipeda University after restoration of independence}

Historically, the development of pedagogy at KU was closely linked to Šiauliai Pedagogical Institute (ŠPI). The Faculty of Pre-school Education at ŠPI ${ }^{9}$ had expertise in training educators: they employed experienced teaching staff and proved their research potential through long-established and meaningful academic traditions. From 1975 to 1991, the faculty was located at the current Faculty of Pedagogy of KU. Prior to 1991, pedagogy as an academic discipline consolidated its status in Western Lithuania by the Baltic Sea in Klaipeda region. ${ }^{10} \mathrm{KU}$ Faculty of Pedagogy possesses a specific geopolitical history and regional educational traditions. ${ }^{11}$

Klaipeda underwent structural transformations after the restoration of independence. Lithuania had only one university, Vilnius University, before the National Awakening; all the other academic studies took place in higher education institutions referred to as 'institutes' or 'academies.' ${ }^{12}$ During the first stage of higher education reform, most of the institutes and academies were restructured, changing their names, merging, and, thus, establishing new universities and assigning new autonomous functions to separate divisions. ${ }^{13}$ In this context, the long-cherished idea of having a university in Klaipeda began.

Some of the most significant prerequisites for establishment of the University included historical, geopolitical, and geographical aspects, which highlighted the changing socio-cultural and economic needs of the region. Additionally, the necessity for decentralisation of research and studies in the country mobilised the potential of higher education, not only in the capital Vilnius but also in other Lithuanian cities. ${ }^{14}$

${ }^{9}$ G. Lukauskienè, A. Zulumskytè, 'Pedagogu rengimo raida Klaipedoje 1902-1975 metais: nuo Seminarijos iki Pedagogikos fakulteto' [The development of teacher training in Klaipeda University in 1902-1975: from Seminary to the Faculty of Pedagogy], Tiltai [Bridges], no. 11, 2002.

${ }^{10}$ Klaipeddos universiteto Pedagogikos fakultetas 1935-2005 [The Faculty of Pedagogy of Klaipeda University in 1935-2005], Klaipėda, KU Publishing House, 2005, pp. 4-5.

11 A. Juška, Mažosios Lietuvos mokykla [The school of Lithuania Minor], Klaipèda, KU Publishing House, 2003, pp. 4-10.

12 A. Zulumskyte, 'Higher Education in Lithuania,' in I. Kestere, A. Kruze (eds.), History of Pedagogy and Educational Sciences in the Baltic Countries from 1940 to 1990: an overview, Riga, RaKa, 2013, pp. 156-163.

13 'Law on Science and Studies of the Republic of Lithuania', Official Gazette [State News], 1991, no. 7-191; R. Želvys, 'Aukštojo mokslo plètra ir akademine didaktika' [The development of higher education and academic didactics], Acta paedagogica Vilnensia, no. 14, 2005, p. 170.

${ }^{14}$ S. Vaitekūnas, Klaipèdos universitetas. 25 metai mokslo ir kultūros židiniui prie jūros [Klaipèda University. 25 years for the centre of science and culture by the sea], Klaipeda, KU Publishing House, 2016, p. 20. 
The merger of higher-education institutions in Klaipeda resulted in the founding of KU on 1 January $1991 .^{15}$ Initially, three faculties were established, and the Faculty of Pedagogy was the most important. The Faculty of Pedagogy served as a foundation for KU because of its strong, independent facilities and its solid academic status as a centre of pedagogical culture and research in Lithuania. Similar to the majority of other universities in the country, KU was established with sufficient material resources and a highly-qualified academic staff.

Despite a strategy of training specialists for the needs of a port town, the supporters of the establishment of KU saw primarily a centre for humanism and culture in the region. ${ }^{16}$ Thus, previously acquired expertise and experience of the Faculty of Pedagogy significantly contributed to development of the new university. A significant increase in the number of higher education institutions and students ${ }^{17}$ was one of the most tangible results of higher education reform. Higher education gradually turned into a mass phenomenon, ${ }^{18}$ as in many other countries of the world.

\section{Academic challenges to the Faculty of Pedagogy}

At the start, the KU Faculty of Pedagogy united all the departments of the Faculty of Pre-school Education of the former ŠPI - General Pedagogy, Educational Methodologies, Childhood Pedagogy, Psychology, Art Pedagogy, and Physical Education. The number of academic staff did not change significantly. With the emergence of new higher education institutions in Lithuania, the number of students in the Faculty gradually decreased and numbers of students in individual programmes were modest. ${ }^{19}$

The changes in higher education in Lithuania directly influenced the Faculty and resulted in re-profiling of specialist training. So, the only higher education institution in the country to train pre-school education specialists (with a focus on psychology and music) was forced to close programmes of a narrow scope. Juozas Rauckis, Dean of the Faculty of Pre-school Education at the Klaipeda

15 'Resolution of the Government of RL No. 299 of 28 September 1990 'On Establishment of University of Klaipeda.'Available: https://www.e-tar.lt/portal/lt/legalAct/TAR.DD7490EE8A7E (accessed 12.03.19).

${ }^{16}$ S. Vaitekūnas, Klaipèdos universitetas. 25 metai mokslo ir kultūros židiniui prie jūros [Klaipèda University. 25 years for the centre of science and culture by the sea], Klaipeda, KU Publishing House, 2016, p. 25.

17 'Švietimas, kultūra ir spauda' [Education, culture and press], in Lietuvos statistikos metraštis [Statistical yearbook of Lithuania], Vilnius, Lietuvos statistikos departamentas, 2004, p. 224.

${ }^{18}$ I. Tinfavičiené, 'Istoriné universitetinio aukštojo mokslo sampratos raida' [Historical development of the concept of higher education and its values], Acta paedagogica Vilnensia, no. 19, 2007, p. 192.

19 A. Lukoševičius, Pedagogikos fakultetas. Klaipédos universitetas [Faculty of Pedagogy. Klaipeda University], Klaipeda, KU Publishing House, 2000, p. 134. 
branch of ŠPI, ${ }^{20}$ noted emerging competition among similar schools of higher education, a truly revolutionary innovation for the academic community of the Faculty: this necessitated a search for programmes that were exceptional and relevant in the labour market and that would immediately train new teaching staff and researchers who were able to teach competently and generate fresh ideas in education.

The possibility of integrated training for primary and pre-school teachers was considered in 1991: five specialisations were planned as well as new specialities in social care and welfare. ${ }^{21}$ Although the newly formed Faculty changed its profile, the main purpose - to train highly qualified teachers for Klaipeda and the region of western Lithuania - remained the same. This was a huge challenge because the Faculty of Pedagogy at ŠPI had strong and longstanding traditions in training primary education specialists only. The Pedagogy Faculty became one of the divisions of the newly formed Šiauliai University as a result of the reform..$^{22}$

It should be mentioned that the programme Childhood Pedagogy, which was introduced in the KU Faculty of Pedagogy in 1991/1992, was exceptional and the only one in the country to open new perspectives for the development of new specialities and specialisations as well as for intensified research in the field of education.

\section{Challenges to teaching and research staff and students}

The development of pedagogy at $\mathrm{KU}$ and reform of higher education as a whole posed many challenges for academic and practical innovations in the field of teaching and research because they took place during general educational innovation in Lithuania. The changes included reorganization of institutions, renaming of specialties and faculties, and adjustment of the system of academic degrees.

The role of education leaders during this period was crucial. Innovation in Lithuania education as a whole was based on the initiatives of Meile Lukšiene ${ }^{23}$ and others; Audronè Juodaityte ${ }^{24}$ for example, led the changes at KU, including childhood social-educational concepts. ${ }^{25}$

20 'Historical Development of the Faculty of Pedagogy of Klaipeda University in 1975-2001. Memories of Professor J. Rauckis about the Period of ŠPI and the Beginning of Establishment of KU,' 2002, A. Zulumskytë's personal archive, Ap. no. 2, p. 1.

${ }_{21}$ 'The Minutes of the Meeting of Supreme Council Presidium of 22 January 1991,' KU Archives, Ap. 1, B. 2, p. 20.

22 Šiauliu universiteto Edukologijos fakulteto istorija ir dabartis 1960-2005 [The history and present of the Faculty of Education Science of Šiauliai University: 1960-2005], Šiauliai, ŠU Publishing House, 2005.

${ }^{23}$ M. Lukšienè, Jungtys [Connectors], Vilnius, Alma littera, 2000.

${ }^{24}$ Audrone Juodaityte - Professor, habilitated Doctor - was Head of the Department of Childhood Pedagogy from its establishment in the Faculty of Pedagogy of at KU.

${ }^{25}$ A. Juodaityté, Vaikystés fenomenas: socialinis-edukacinis aspektas [The phenomenon of childhood: Socio-educational aspect], Klaipeda, KU Publishing House, 2003. 
Many scholars worked during the initial stages of the Faculty of Pedagogy; however, new academic realities certain challenges on employees in research institutions. In 1992, the Lithuanian government approved the New Procedure of Nostrification of Research Degrees and Pedagogical Titles and Registration of Diplomas (Certifications). ${ }^{26}$ Regulations were introduced that served as basis for reviewing research degrees and titles obtained during the Soviet era: the Candidate of Sciences diploma granted previously was declared equivalent to a diploma of a Doctor of Science and the Soviet Doctor of Science degree was equated to a Doctor Habilitatus degree. ${ }^{27}$

Prominent and nationally recognised scholars in education, who successfully combined their research and teaching activities, worked in the Faculty of Pedagogy of Klaipeda University after successful nostrification. The practice of conducting research while teaching students was a tradition inherited from the Soviet era and gained strength after regaining independence. Today, many university professors must take up not only research, but also teach, which deprives them of the right to choose only one area of activity - research or teaching. ${ }^{28}$

In 2002, the Department of Pedagogy was re-named the Department of Education. ${ }^{29}$ Changes in the names of institutions illustrate another significant transformation in Lithuanian education sciences: after restoration of independence, the academic community engaged in intensive discussion regarding new and relevant terms in education sciences, or Pedagogy, as it was called during the Soviet era. ${ }^{30}$ Education sciences were renamed 'educology' and added as a branch of social sciences; ${ }^{31}$ researchers were referred to as 'educologists'. Pedagogy, a sub-branch in educology, ${ }^{32}$ now embraced the concept of education of children and the young generation only.

26 'Resolution of Government of RL No. 549 of 15 July 1992 on Procedure of Nostrification of Research Degrees and Pedagogical Titles and Registration of Diplomas (Certifications).' Available: https://www.e-tar.lt/portal/lt/legalAct/TAR.3882FC59D350 (accessed 14.04.18).

27 'Resolution of Government of RL No. 204 of 31 March 1992 On the System of Research Degrees and Pedagogical Titles of the Republic of Lithuania and Procedure of Their Granting,' Official Gazette [State News], no. 16-452, 1992.

${ }_{28}$ B. Jatkauskienè, R. M. Andrikienè, Universiteto destytoju veiklos daugiafunkcionalumas profesionalizacijos kontekste [Multifunctionality of university teachers' activities in the context of professionalization], Klaipeda, KU Publishing House, 2013, p. 36.

29 'Apie Pedagogikos katedrą' [On the Department of Pedagogy]. Available: http://www.ku.lt/ humf/ pagrindinis/struktura/pedagogikos-katedra/ (accessed 14.03.18)

${ }^{30}$ Discussions were led by prominent scholars as Prof. Dr. habil. Leonas Jovaiša, who was working at Vilnius University. See L. Jovaiša, Edukologijos įvadas [Introduction to education science], Kaunas, Technologija, 1993.

31 'Resolution of Government of RL No. 1245 of 11 November 1997 on Classification of Study and Research Areas, Fields and Branches.' Available: https://www.e-tar.lt/portal/lt/legalAct/ TAR.3BEC81E1B099 (accessed 15.04.18)

32 'Order of the Ministry of Education No. 30 of 9 January 1998. On the Classification of Study and Research Areas, Fields and Branches.' Available: https://www.e-tar.lt/portal/lt/legalAct/ TAR.6FDAC10F3267 (accessed 14.04.19) 
It should be mentioned that promotion of writing and presenting academic publications at the Faculty was also tied to the new Procedures for Attestation of academic staff, which is still valid. ${ }^{33}$ According to Klaipeda University documents, every teacher who wanted to get a desirable position in research and teaching at the University had to take part in competitions for specific positions. After winning the competition and working for five years (in some cases, three), the procedure of attestation would assess teaching expertise, professional development data, participation in conferences, the number of national and international publications, and other parameters. For this reason, many academics were forced to teach between four and eight (and sometimes independent) study courses to students in various programmes during one academic year. This assigned a particularly heavy annual teaching load to staff, according to KU-approved teaching load norms, a result of the University's money-saving policies. ${ }^{34}$ Therefore, it can be stated that the activities of academics and researchers at the Faculty of Pedagogy were particularly multisided and intensive.

Another innovation in Lithuanian higher education institutions was a new procedure for formalisation and justification of programmes, and courses (subjects). For example, programme descriptions were replaced by study modules with detailed descriptions of goals, objectives, and competencies to be developed and learning outcomes to be achieved. In addition, new procedures were also approved: after five years after implementation of a new programme, self-assessment of all established parameters had to be carried out and results had to be submitted for external international audit. A commission of experts from foreign universities evaluated the program, its processes and outcomes, and made recommendations on further development. ${ }^{35}$

Complicated economic conditions at the turn of the $21^{\text {st }}$ century required Faculty of Pedagogy academic staff to complete all that work themselves. They formed workgroups, working after lectures and on weekends, intensively studying documents, writing reports, conducting student opinion surveys, filling in various tables, etc. ${ }^{36} \mathrm{~A}$ similar situation occurred in other Lithuanian higher education institutions, clearly evidence of devotion by academic staff to their mission, diligence, and even sacrifice while seeking to consolidate programmes and ensure their quality.

33 'Resolution of KU Senate No. 11-48 of 5 April 2013 The Description of Procedure for Attestation and Coopetition for Taking Positions of Teachers, Research Workers and Researchers in Klaipeda University.' Available: http://briai.ku.lt/downloads/KU/20130405_11_48.pdf (accessed 15.04.19)

${ }_{34}$ 'Resolution of KU Senate No. 11-52 of 23 May 2003 on Workload Norms and Timesheets of Teaching Load in the Academic Year 2003/2004, Received documents, 2003, The Archives of Department of Pedagogy, pp. 1-2.

35 'Self-assessment Report in the Study Field of Education Science of 2004 in Klaipeda University (2 study programmes),' 2004, The Archives of Department of Pedagogy of KU.

${ }^{36}$ Based on memoirs of the author and faculty members and handwritten notes and memos in personal archives. 
It is important to point out that exhaustive methodological and didactic materials were available to teachers working in schools. However, higher education didactics, as a support system for a professor in higher education, evolved gradually and only fragmentarily. ${ }^{37}$ The practice of teaching adult learners (andragogy) was underdeveloped, but in the $21^{\text {st }}$ century, the development of adult education as an academic discipline gained momentum and numerous teaching aids and research on the topic were prepared at the KU Faculty of Pedagogy.

The increasing European requirements that determined changes in teaching staff, physical environment, and conditions for education in the 1990s must be mentioned. Academic staff memories indicate that the number of new, integral courses and sources of learning grew (completely new elective courses and compulsory and recommended literature was introduced). Requirements for academic publications increased (publications in foreign languages, especially in English) as did use of new, contemporary methodologies and strategies of research. Mature students chose to study at the Faculty and their insistence on high standards of teaching increased. Concrete course outcomes and assessment criteria were required by students, discussions between students and professors began, and detailed course descriptions were developed.$^{38}$ Lecturers had to adjust to a new system of study credits and change to a 10-point assessment system instead of the previous 5-point one. These examples illustrate the intensive and multi-functional activities of teaching staff during this period.

Evaluation of the most significant changes faced by students reveals that some students experienced them as a new transformation if the political changes had occurred during their studies. But newly enrolled students perceived the reforms as causalities. Intensive changes in the subjects and their titles were introduced after 1990: subjects such as the History of the Communist Party of the Soviet Union, Political Economy of Socialism, Basics of Scientific Atheism, Scientific Communism, and Soviet Law $^{39}$ were abolished. A lack of new literature sources (particularly in English) was another challenge because the absolute majority of foreign literature was in Russian. ${ }^{40}$ Similar to teaching staff, students were also forced to change their usual understanding about

${ }^{37}$ B. Jatkauskiene், R.M. Andrikienè, Universiteto dèstytoju veiklos daugiafunkcionalumas profesionalizacijos kontekste [Multifunctionality of university teachers' activities in the context of professionalization], Klaipedda, KU Publishing House, 2013, pp. 49-50.

38 'Historical development of the Faculty of Pedagogy of Klaipeda University in 1975-2001. Memories of Professor J. S. Pocienè about the Period of ŠPI and the Beginning of Establishment of KU,'2002, A. Zulumskytës personal archive, Ap. no. 1, 2002, p. 1.

39 'Historical Development of the Faculty of Pedagogy of Klaipeda University in 1975-2001. Certification to Diploma MB No. 133263 of Šiauliai Pedagogical Institute (diploma supplement), 2002, A. Zulumskytës personal archive, Ap. no. 4, pp. 1-2.

40 'Historical Development of the Faculty of Pedagogy of Klaipeda University in 1975-2001. Memories of S. Balčytiené, an employee of the Library of the Faculty of Pedagogy about the Period of ŠPI and the Beginning of Establishment of KU, 2002, A. Zulumskytës personal archive, Ap. no. 6, p. 1. 
studies in higher education institutions because the system, its structure, and requirements underwent drastic changes.

\section{System and content of studies at KU Faculty of Pedagogy}

The year 2000 was marked by an exceptional breakthrough in the entire structure of Lithuanian higher education: the Law on Higher Education of Lithuania was adopted, which provided for a binary system of higher education consisting of a university sector and a non-university sector. ${ }^{41}$

The law determined how university studies, scientific research, and experimental development would be conducted and (or) professional art would be developed in universities. The other type of higher education institutions was colleges that offered studies in and focused on applied scientific research. ${ }^{42}$ Thus, colleges were established in Lithuania in 2000, and by 2001, five colleges had opened in Klaipeda. ${ }^{43}$ Although many colleges were created from former advanced vocational schools, they were still granted higher education institution status, which meant that some study programmes, including pedagogy, became a source of competition for the University and colleges. Faculty of Pedagogy attempts to solve this problem included shortened study programmes in education sciences that admitted exceptional graduates from colleges. ${ }^{44}$

As early as in 1992, joint doctoral study programmes in Education Sciences and Psychology with other Lithuanian universities ${ }^{45}$ were introduced at KU. This was a necessary response to the lack of young, qualified scholars in the University and the need to develop research in academic fields in Western Lithuania. Another exceptional aspect of the Faculty of Pedagogy can be distinguished: by 2001, a complete three-cycle study structure (BA, MA, PhD) had been formed, creating favourable conditions for academic preparation of the highest level. ${ }^{46}$

41 'The Law on Higher Education of RL', Official Gazette [State News], 2000, no. 27-715.

${ }^{42}$ The college is a higher-education institution in Lithuania that provides (non-university) education. Colleges pay more attention to practice, but the university provides an academic education.

${ }^{43}$ 'Švietimas, kultūra ir spauda' [Education, culture and press], Lietuvos statistikos metraštis [Statistical yearbook of Lithuania], Vilnius, Lietuvos statistikos departamentas, 2004, p. 224.

44 'Historical development of the Faculty of Pedagogy of Klaipeda University in 1975-2001. Memories of Professor V. Raudys about the Period of ŠPI and the Beginning of Establishment of KU,' 2002, A. Zulumskyte’s personal archive, Ap. no. 7, p. 2.

45 'Resolution of Government of RL of 7 October 1992 'On Establishment of Doctoral Studies in Research and Educational Institutions.'Available: https://www.e-tar.lt/portal/lt/legalAct/ TAR.2CCCC0BDE2CA/TAIS_152147 (accessed 14.04.18).

46 'Mokslas ir menas Klaipedos universitete 2001' [Science and art in Klaipeda University 2001], Information publication, vol. 3, Klaipeda, KU Publishing House, 2002. 
The three-cycle system, consisting of Bachelor's, Master's and Doctoral studies, replaced the previously implemented integrated studies. ${ }^{47}$ By 2001, ten Master's programmes had been registered and implemented: Pedagogy of Preschool Education, Pedagogy of Primary Education, Management of Education, Family Studies, History of Pedagogy, Pedagogical Psychology, Social Pedagogy, Childhood Pedagogy, Pedagogy of Physical Education, and Pedagogy of Religious Education. ${ }^{48}$ The Master's study programme was broad ${ }^{49}$ and valued highly from the perspective of research and practical professional activity.

Other elements of the programme can also be distinguished: marketable and flexible university study programmes were created involving academic and social partners; particular attention was paid to further development of Master's programmes and continuous study programmes; ${ }^{50}$ intensive investment was put into creating additional specialisations in Bachelor's and Master's studies (classroom teacher with additional qualifications in music, arts, English); and development of new programmes in general. ${ }^{51}$ In 2002, new Bachelor's programmes were implemented (Education Sciences, Catechetics, and Mathematics and Informatics teaching), and Master's programmes in Adult Education and Arts Pedagogy were submitted for state registration. ${ }^{52}$

In 2003/2004, research and teaching in the Faculty was conducted in eight departments: Childhood Pedagogy, Education, Psychology, Methodologies of Education, Arts Pedagogy, Catechetics, Physical Education, and Social Pedagogy. Researchers in all departments conducted studies in two inter-faculty topics of psychology and education sciences introduced in 2000 - Research on Expression and Development of Education at the Junction of Classicism and Modernism and Research on Social Psychological Development of Children and Young People. ${ }^{53}$ Development of Master's studies resulted in considerable attention on research activities of students: in 2000/2001, annual Master's student academic conferences were initiated by professor Ona Tijūnèlienè and associate professor Aušrinè Zulumskytè. Young researchers could present their projects by participating in academic debates and strengthen their research competences.

${ }^{47}$ Integrated programmes were used by an association or consortium of 3-4 universities to prepare students at the doctorate level in a certain field. For example, four universities, under uniform conditions, trained doctors of educology.

48 A. Lukoševičius, Pedagogikos fakultetas. Klaipėdos universitetas [Faculty of Pedagogy. Klaipèda University], Klaipedda, KU Publishing House, 2000, p. 134.

49 Broad profile studies meant that a trained specialist could work not in a narrow field but both in science and in practice with a new wide range of knowledge and skills.

${ }^{50}$ Continuing education programs - programs for in-service training, professional development, or for those who wanted/needed to change their profession.

51 'The Self-assessment Report in the Study Field of Education Science of 2002 (5 study programmes),' manuscript, 2002, Archives of Department of Pedagogy of KU, p. 8.

52 Ibid., p. 7.

53 'Mokslas ir menas Klaipèdos universitete 2000', Information publication, vol. 2, Klaipėda, KU Publishing House, 2001, pp. 162-186. 


\section{The future of the KU Faculty of Pedagogy: opinions of students and professors in 2002}

Teacher and student opinion surveys became a tradition in the Faculty of Pedagogy in addition to formal evaluations of academic and artistic activities, minutes of meetings, and self-assessment reports: these allowed identification of positive and negative developments in the Faculty and forecasting of future opportunities. Gražina Lukauskienës and my 2002/2003 report $^{54}$ contains $^{2}$ statistical data and participants' comments on the process of education that clearly illustrates some problems. Our survey included nine professors and 85 students, who were divided into two groups on the basis of their study experience. The aim was to gather information on how life in the faculty was perceived and to evaluate its positive and negative aspects. All recipients were provided analogous questions; only generalised tendencies in opinions and insights will be highlighted.

Positive Faculty evaluation. Highly diverse answers were received about what the respondents liked most in the Faculty of Pedagogy. Bachelor's programme students commented most frequently on the qualifications of academic staff, appropriateness of information, and acceptable methods of teaching. Master's programme students emphasised encouragement and motivation received from professors. In general, professors were looked upon as positive examples of learning and coping.

Responses from academic staff showed that the historical environment of the Faculty was important to the majority as teacher training had been organised in the Faculty since the beginning of the $20^{\text {th }}$ century. They also stressed the introduction and development of exceptional programmes in the Faculty, specifically the integral Bachelor's programme of Childhood Pedagogy and the interesting and relevant specialisations in Bachelor and Master's studies.

With regard to the relationship between students and their professors, Bachelor's programme students most frequently mentioned tolerance and sincerity of the academic staff and that they felt appreciated as individuals. Master's programme students frequently mentioned positive mutual collaboration, particularly the professors' understanding that the majority of Master's programme students were working people.

The professors frequently stated that they appreciated mutual openness and collaboration, emphasising that during the Soviet era, relationships between students and teachers were almost exclusively formal.

Negative evaluation of the Faculty. A variety of negative opinions were revealed about the Faculty. Students of all levels referred to insufficient literature and poor learning facilities, i.e., unavailability of equipment, special laboratories, and computers. Some student respondents singled out nonobjective evaluations and assessments as a negative factor. Master's programme

\footnotetext{
${ }^{54}$ A. Zulumskytè, G. Lukauskienè, 'Pedagogikos fakulteto studentų ir dėstytojų tyrimo ataskaita (2002/2003 m.m.)' [The reports on opinion surveys of teachers and students of the Faculty of Pedagogy in 2002/2003], manuscript, Archives of Department of Pedagogy of KU, pp. 1-15.
} 
students elaborated on issues of the quality of studies stating that they were too theoretical. Also, overlapping of subjects in Bachelor and Master's programmes was criticised. Despite the fact that a considerable number of teachers and students pointed to very democratic and constructive relationships, about one fourth of the respondents indicated teacher arrogance and barriers in communication such as supremacy of their knowledge and their position.

Such positive and negative evaluations must have been influenced by personalities - personal qualities and specific actions of teachers with whom the respondents communicated and worked. Problems of devising timetables in Bachelor's studies and other organisational shortcomings were mentioned among the difficulties encountered by students.

The survey of professors indicated that the growing number of full-time and part-time students who studied and worked simultaneously was considered a problem. According to academic staff, this impeded consistent learning, high achievement, and solid professional preparation.

One question was related to evaluation of academic traditions in the Faculty. Student life in the Faculty in 1990 was rich in events and quite colourful: artistic amateur collectives, professional festivals, contests, sports festivals, freshmen inauguration, "medium" studies events ${ }^{55}$ and other activities ${ }^{56}$ were not in short supply. Over the course of time, as students needed to combine studies with work, student traditions gradually deteriorated: although more than half of the students expressed a positive opinion about student life, as many as one third of them stated that they were not well informed about student festivals or did not have time to take part in student activities. Students agreed unanimously about the necessity for new traditions and new events, but none of the respondents gave any concrete suggestions. This may have been influenced by a shift in social activities, which was linked to economic realities rather than student self-realisation.

The absolute majority of professors felt some nostalgia for previous proactiveness of students and claimed that current students lacked activity and initiative. Regarding the challenges encountered in their work, professors did not emphasise their teaching and research workload, poor working conditions, or low wages that fell even more during the economic recession. This manifested in enthusiasm and devotion by academic staff for their work and a sense of responsibility towards students. This correlates with other memoirs of staff members. ${ }^{57}$

Attitude towards the future of the Faculty. More than half of the students in the Bachelor's study programme expressed optimistic views about the future of the Faculty in 2002: they believed in the future economic prosperity of

\footnotetext{
${ }^{55}$ The 'medium' - students' traditional festival to celebrate the half-term practiced in Medieval times.

56 'Historical development of the Faculty of Pedagogy of Klaipeda University in 1975-2001. Memories of Professor L. Žukauskienè about the Period of ŠPI and the Beginning of Establishment of KU, 2002, A. Zulumskytës personal archive, Ap. no. 5, p. 2.

57 Ibid.
} 
the Faculty, renovation of a nice historical building, and introduction of new specialities. Master's students were divided: only one-third of the respondents evaluated academic and research possibilities positively, and $40 \%$ of the respondents were sceptical. They expressed concern about demographic tendencies and the fall in the number of children (potential pupils) and, consequently, about the decline in teaching opportunities.

Academic staff targeted a more general range of problems and were more positive: professors were more optimistic compared to the students. The majority of respondents pointed out that despite the fact that the Faculty was going through a complicated period, the number of trained teachers was large and not everybody could find a job. In addition, faculty members noted that it was necessary for western Lithuania to have a centre of academia and culture. Staff members emphasised that it was necessary to retain long-established traditions of teacher training and expertise and to be flexible to new requirements and challenges of the labour market in a changing economic and political situation.

\section{Conclusion}

The most significant prerequisites for the establishment of Klaipeda University and the Faculty of Pedagogy include historical, geopolitical, and geographical factors, which highlighted changing socio-cultural and economic needs of Western Lithuania, resulting from the decentralisation of science and studies and mobilisation of potential for higher education in regional Lithuanian cities.

After 1990, the newly established Faculty of Pedagogy changed its focus but the long-established strategy for training highly qualified educators for Klaipeda and its region remained. Among the most serious challenges imposed on the faculty were unusually competitive conditions between higher education institutions offering similar courses of study, the necessity to search for study programmes that were exceptional and relevant for the labour market, and prompt preparation of new academic staff who could teach and research in a competitive way.

Academic authorities played a significant role in Lithuanian higher education and in the development of the Pedagogical Faculty of KU in the 1990s: they made numerous positive decisions that contributed to bringing pedagogical higher education closer to global progressive and innovative practices.

By 2004, the community of the Faculty of Pedagogy of KU encountered numerous changes, which turned into difficult challenges. Faculty professors had to adapt to heavy teaching loads, meet new requirements for research publications, improve their competences by developing new study programmes, implement new requirements for descriptions of subjects, self-assess programmes, and develop student assessment. The staff and their devotion to academic activity had a significant impact on the development of education sciences and successful work with students. During the tense economic period in the country, the activities of such individuals became positive examples to 
students, who also made attempts to adjust to new requirements in the study processes in higher education institutions.

Analysis of the data collected in the academic year 2002/2003 revealed positive and negative aspects in academic processes. Collaboration with professors and good interpersonal relations were mentioned among the most significant achievements. Participating professors emphasised the emergence and development of new, even exceptional, programmes in the Faculty. Students pointed out insufficient literature and excessive theorisation of studies as challenges encountered. Many professors expressed concern regarding issues of study quality because of students' needs to combine studies with work. They also expressed concern about declining academic traditions and insufficient student activity. It should be emphasised that the majority of members of the Faculty community expressed positive expectations about the future of the Faculty.

However, it is also necessary to note that after 2004, when Lithuania joined the European Union, the strategic objectives of higher education institutions, curriculum, and forms of studies underwent other significant qualitative and quantitative changes. Transformations that occurred in Lithuanian higher education from 1990 to 2004 and specifically in one division of a regional university can be regarded as intermediate events that are projections of future possibilities. 